\title{
The depletion of PinX1 involved in the tumorigenesis of non-small cell lung cancer promotes cell proliferation via p15/cyclin D1 pathway
}

\author{
Xiao-Peng Tian ${ }^{1,2 \dagger}$, Xiao-Han Jin ${ }^{2 \dagger}$, Mei Li ${ }^{3 \dagger}$, Wei-Juan Huang ${ }^{1 \dagger}$, Dan Xie ${ }^{2}$ and Jia-Xing Zhang ${ }^{1,4^{*}}$
}

\begin{abstract}
Background: The telomerase/telomere interacting protein PinX1 has been suggested as a tumor suppressor. However, the clinical and biological significance of PinX1 in human non-small cell lung cancer (NSCLC) is unclear.

Methods: PinX1 gene/expression pattern and its association with NSCLC patient survival were analyzed in cBioportal Web resource and two cohorts of NSCLC samples. A series of in vivo and in vitro assays were performed to elucidate the function of PinX1 on NSCLC cells proliferation and underlying mechanisms.

Results: More frequency of gene PinX1 homozygous deletion and heterozygote deficiency was first retrieved from cBioportal Web resource. Low expression of PinX1 correlated with smoking condition, histological type, T stage, N stage, M stage and TNM stage, and was an independent predictor for overall survival in a learning cohort $(n=93)$ and a validation cohort $(n=51)$ of NSCLC patients. Furthermore, knockdown of PinX1 dramatically accelerated NSCLC cell proliferation and G1/S transition, whereas ectopic overexpression of PinX1 substantially inhibited cell viability and cell cycle transition in vitro and in vivo. p15/cyclin D1 pathway and BMP5 might contribute to PinX1associated cell proliferation and cell cycle transition.
\end{abstract}

Conclusion: The cost-effective expression of PinX1 could constitute a novel molecular predictor/marker for NSCLC management.

Keywords: PinX1, Non-small cell lung cancer, BMP5, Cell cycle, P15

\section{Background}

Globally, lung cancer is a major clinical problem, which is one of the leading causes of cancer mortality, resulting in more than 2 million deaths each year [1]. Non-small-cell lung cancer (NSCLC) accounts for about $85 \%$ of all lung cancer, with 5 year-survival of less than 20\% [2]. Early diagnosis represents one of the most effective strategies in improving survival and prognosis of lung cancer patients [3-5]. Therefore, it is important to understand the molecular mechanism in NSCLC tumorigenesis in order

\footnotetext{
* Correspondence: jxzhangsysu@163.com

${ }^{\dagger}$ Equal contributors

'Zhongshan School of Medicine, Sun Yat-Sen University, Guangzhou, China ${ }^{4}$ Department of Oncology, The first Affiliated Hospital, Sun Yat-Sen University, No.58, Zhongshan Second Road, 510080 Guangzhou, China

Full list of author information is available at the end of the article
}

to identify biomarkers for early diagnosis and management of NSCLC.

PinX1 was first identified in a yeast two-hybrid screen as TRF1-binding protein and this genetically conserved nuclear protein was shown to be an endogenous telomerase inhibitor [6-8]. Moreover, it has been demonstrated that PinX1 is a major haplo-insufficient tumor suppressor gene, stemming from its correlation with chromosome instability and cancer initiation [9]. Our group recently reported that not only does PinX1 contribute to telomerase activity and cancer tumorigenicity but it also increases the sensitivity of cancer cells to DNA damage and chemo-radiotherapy [10-12]. In addition, recent studies have shown that PinX1 could suppress cell cycle progression [13-16]. PinX1 was also shown to arrest cell cycle on spindle assembly checkpoint 
and this associate with its localization during different stage of cell cycle. It in turn influences cancer cell proliferation and taxol sensitivity $[17,18]$.

Although there is mounting evidence suggesting PinX1's role in cancer development and progression [19-22]. We have not seen any reports of its involvement in pathogenesis and tumorigenesis of NSCLCs. Here we provided the connection and identified the potential molecular mechanisms for PinX1 to promote NSCLCs. In this study, we first described the expression pattern of PinX1 in human NSCLC tissues. We also demonstrated that low expression of PinX1 correlated with smoking condition, histological type, T stage, $\mathrm{N}$ stage, $\mathrm{M}$ stage and TNM stage, and was an independent predictor for overall survival in NSCLC patients. Furthermore, the function and mechanisms studies of PinX1 suggest that PinX1-arrested cell cycle transition accounts for the NSCLC's cell proliferation. In addition, p15/cyclin D1 pathway and BMP5 might contribute to PinX1-associated cell proliferation and cell cycle transition.

\section{Methods \\ Analysis of NSCLC data in CBioportal for Cancer Genomics database}

The cBioPortal for Cancer Genomics is an open-access downloaded bio-database, providing visualization and analyzing tool for large-scale cancer genomics data sets (http://cbioportal.org). This portal collected records that were derived from 147 individual cancer studies, in which 31 types of cancer were analyzed, which included over 21000 samples [23, 24]. Analysis of the 1788 NSCLC samples (1098 lung adenocarcinoma cases and 682 lung squamous cell carcinoma cases) from this database was performed in silico.

\section{Patients and tissue specimens}

Ninety-three NSCLC patients from the Department of Radiotherapy, Cancer Center, Sun Yat-Sen University between January 2008 and December 2014 were assigned as learning cohort. Another 51 NSCLC cases in the same period from the first Affiliated Hospital, Sun Yat-Sen University were assigned as validation cohort. These cases were selected based on the availability of resection tissues and follow-up data. All selected cases had not received preoperative radiation or chemotherapy before diagnosis biopsies. All samples were classified according to the TNM (UICC, 2014) staging and evaluated for histological type by the same pathologist. The study was approved by the Medical Ethics Committee of the two institutions and involved only informed consent patients. The clinical-pathological characteristics of the two cohorts are summarized in Table 1.
Immunohistochemistry (IHC)

Slides were dried overnight at $37^{\circ} \mathrm{C}$, dewaxed in xylene, rehydrated with graded alcohol, and immersed in 3\% hydrogen peroxide for 20 min to block endogenous peroxidase activity. For antigen retrieval, tissue slides were boiled in tris (hydroxymethyl) aminomethane-EDTA buffer ( $\mathrm{pH}$ 8.0) in a pressure cooker for $10 \mathrm{~min}$. The slides were incubated with $10 \%$ normal rabbit serum at room temperature for $20 \mathrm{~min}$ to reduce nonspecific interactions. Subsequently, tissue slides were incubated with anti-PinX1 antibody (1:200, ProteinTech Group, Inc.) for $60 \mathrm{~min}$ at $37^{\circ} \mathrm{C}$ in a moist chamber. After five rinses with $0.01 \mathrm{~mol} / \mathrm{L}$ phosphate-buffered saline (PBS, $\mathrm{pH}=7.4$ ) for $10 \mathrm{~min}$, the slides were incubated with a secondary antibody (Envision, Dako, Glostrup, Denmark) at a concentration of 1:100 for $30 \mathrm{~min}$ at $37^{\circ} \mathrm{C}$, followed by PBS washes and finally stained with DAB (3,3-diaminobenzidine). The nucleus was counterstained with Meyer's hematoxylin. PBS alone was used as a negative control.

\section{Immunohistochemistry evaluation}

PinX1 immunoreactivity was classified by receiveroperator curve (ROC) analysis: (1) low expression defined as less than $65 \%$ PinX1 positive cells and (2) high expression defined as greater than $65 \%$ PinX1 positive cells. BMP5 positive staining was also divided into low expression cases (cases with score 0-6) and high expression (cases with scores 8-12). (See Additional file 1: Supplementary Materials and Methods).

\section{Quantitative real-time polymerase chain reaction (qRT- PCR) analysis}

The construction of PinX1 and GAPDH sense/antisense primers has been previously described [10]. RNA was reverse-transcribed using SuperScript First Strand cDNA System (Invitrogen, USA) according to the manufacturer's instructions. qRT-PCR was performed using Real-time PCR system (Applied Biosystems, USA) as follows: $50{ }^{\circ} \mathrm{C}$ for $2 \mathrm{~min}, 95^{\circ} \mathrm{C}$ for $10 \mathrm{~min}, 40$ cycles of $95{ }^{\circ} \mathrm{C}$ for $15 \mathrm{~s}$, and $60{ }^{\circ} \mathrm{C}$ for $60 \mathrm{~s}$. The relative levels of gene expression were represented as $\Delta \mathrm{Ct}=\mathrm{Ct}_{\text {gene }}-\mathrm{Ct}_{\text {reference, }}$, and the fold change of gene expression was calculated by the $2^{-\Delta \Delta C t}$ Method.

\section{Cell lines and recombinant lentiviral vector construction} H125, A549, SK-MES-1 and H1299 cells were maintained in DMEM and/or RPMI 1640 supplemented with 10\% fetal bovine serum and $1 \%$ penicillin-streptomycin at $37{ }^{\circ} \mathrm{C}$ in $5 \%$ $\mathrm{CO}_{2}$. The PinX1 cDNA was cloned into the pCDH-CMVEF1-copGFP lentivector (System Biosciences, Mountain View, CA, USA). The PinX1-shRNA lentivirus vector has been previously described $[10,11,16,20]$. The PinX1siRNA transient transfection (GGAGCTACCATCAATAATG) was designed to decrease PinX1 expression temporary. 
Table 1 Association of PinX1 expression with patient's clinicopathological features in NSCLC

\begin{tabular}{|c|c|c|c|c|c|c|c|c|}
\hline \multirow[t]{2}{*}{ Variable } & \multicolumn{4}{|c|}{ Learning cohort } & \multicolumn{4}{|c|}{ Validation cohort } \\
\hline & Cases & $\begin{array}{l}\text { Negative } \\
\text { expression (\%) }\end{array}$ & $\begin{array}{l}\text { Positive } \\
\text { expression (\%) }\end{array}$ & $P$-value ${ }^{*}$ & Cases & $\begin{array}{l}\text { Negative } \\
\text { expression (\%) }\end{array}$ & $\begin{array}{l}\text { Positive } \\
\text { expression (\%) }\end{array}$ & $P$-value* \\
\hline \multicolumn{9}{|l|}{ Age(years) } \\
\hline$<56^{\mathrm{a}}$ & 42 & $21(50 \%)$ & $21(50 \%)$ & 0.068 & 22 & 13(59.1\%) & $9(40.9 \%)$ & 0.443 \\
\hline$\geq 56^{\mathrm{a}}$ & 51 & $35(68.6 \%)$ & $16(31.4 \%)$ & & 29 & $14(48.3 \%)$ & $15(51.7 \%)$ & \\
\hline \multicolumn{9}{|l|}{ Gender } \\
\hline Male & 61 & 39(63.9\%) & $22(36.1 \%)$ & 0.312 & 35 & $17(48.6 \%)$ & 18(51.4\%) & 0.355 \\
\hline Female & 32 & $17(53.1)$ & 15(46.9\%) & & 16 & $10(62.5)$ & $6(37.5 \%)$ & \\
\hline \multicolumn{9}{|l|}{ Smoking Condition } \\
\hline Smoker & 42 & $32(76.2 \%)$ & $10(23.8 \%)$ & 0.004 & 20 & 16(80\%) & $4(20 \%)$ & 0.002 \\
\hline Nonsmoker & 51 & $24(47.1 \%)$ & $27(52.9 \%)$ & & 31 & $11(35.5 \%)$ & $20(64.5 \%)$ & \\
\hline \multicolumn{9}{|l|}{ WHO grade } \\
\hline G1 & 28 & $18(64.3 \%)$ & 10(35.7\%) & 0.708 & 16 & $9(56.2 \%)$ & 7(43.8\%) & 0.843 \\
\hline G2 & 37 & $22(62.2 \%)$ & 15(37.8\%) & & 20 & $11(55 \%)$ & $9(45 \%)$ & \\
\hline G3 & 28 & 16(57.1\%) & $12(42.9 \%)$ & & 15 & $7(46.7 \%)$ & $8(53.3 \%)$ & \\
\hline \multicolumn{9}{|l|}{ Histological Type } \\
\hline Squamous cell carcinoma & 37 & 29(78.4\%) & $8(21.6 \%)$ & 0.002 & 22 & $16(72.7 \%)$ & $6(27.3 \%)$ & 0.046 \\
\hline Adenocarcinoma & 46 & $25(54.3 \%)$ & $21(45.7 \%)$ & & 23 & $9(39.1 \%)$ & $14(60.9 \%)$ & \\
\hline Others & 10 & $2(25 \%)$ & $8(75 \%)$ & & 6 & $2(33.3 \%)$ & $4(77.7 \%)$ & \\
\hline \multicolumn{9}{|l|}{ T stage } \\
\hline $\mathrm{T} 1-\mathrm{T} 2$ & 38 & $15(39.5 \%)$ & $23(60.5 \%)$ & 0.001 & 18 & $4(22.2 \%)$ & 14(88.8\%) & 0.001 \\
\hline T3-T4 & 55 & $41(74.5 \%)$ & $14(25.5 \%)$ & & 33 & 23(69.7\%) & 10(30.3\%) & \\
\hline \multicolumn{9}{|l|}{ N stage } \\
\hline No & 26 & $9(34.6 \%)$ & $15(57.7 \%)$ & 0.005 & 16 & $5(31.2 \%)$ & $11(68.8 \%)$ & 0.036 \\
\hline N1-N3 & 67 & $47(70.1 \%)$ & $22(29.9 \%)$ & & 35 & $22(62.9 \%)$ & $13(37.1 \%)$ & \\
\hline \multicolumn{9}{|l|}{ M stage } \\
\hline MO & 66 & $45(68.2 \%)$ & $21(31.8 \%)$ & 0.014 & 35 & $14(40 \%)$ & $21(60 \%)$ & 0.006 \\
\hline M1 & 27 & $11(40.7 \%)$ & 16(59.3\%) & & 16 & 13(81.2\%) & $3(18.8 \%)$ & \\
\hline \multicolumn{9}{|l|}{ TNM stage } \\
\hline$|-| \mid$ & 25 & $6(24 \%)$ & 19(76\%) & 0.000 & 14 & $4(28.6 \%)$ & 10(71.4\%) & 0.032 \\
\hline III-IV & 68 & $50(73.5 \%)$ & $18(26.5 \%)$ & & 37 & $23(62.2 \%)$ & 14(37.8\%) & \\
\hline
\end{tabular}

${ }^{*}$ Chi-square test; ${ }^{a}$ Mean age; $T$ tumor, $N$ node, $M$ metastases

\section{MTT proliferation assay}

Cellular viability was measured using the MTT proliferation assay (Sigma) according to the manufacture's protocol. In brief, 1000 cells were seeded in 96-well plates and cultured/treated for $24 \mathrm{~h}$. Viability was measured at different time points from $12 \mathrm{~h}$ to $72 \mathrm{~h}$ after posttreatment on the basis of experimental requirement.

\section{Colony forming assay and Western blot analysis}

Approximately 500 cells were seeded in each well of a six plate for $24 \mathrm{~h}$. The media was then replaced with fresh RPMI1640 or DMEM containing 10\% FBS and the cells were maintained for two weeks. Colonies were fixed with methanol and stained with $0.1 \%$ crystal violet in
$20 \%$ methanol for $15 \mathrm{~min}$. Western blot methods were performed with standard procedure [18]. Details may be found in the Additional file 1: Supplementary materials and methods.

\section{EdU incorporation}

EdU is a thymidine analog whose incorporation can be used like BrdU to label cells undergoing DNA replication. Cells were performed using Cell-Light ${ }^{\mathrm{mm}}$ EdU Apollo ${ }^{\oplus} 488$ In Vitro Imaging Kit (Ribobio, Guangzhou China) according to the manufacture's protocol. The EdU positive cells (red cells) were counted using ImagePro Plus (IPP) 6.0 software (Media Cybernetics, Bethesda, MD, USA). The EdU incorporation rate was 
expressed as the ratio of EdU positive cells to total DAPI positive cells (blue cells).

\section{Flow-cytometry analysis and Cell cycle antibody array}

The cells were collected, washed with PBS three times and fixed overnight with cold $70 \%$ clod ethanol at $4{ }^{\circ} \mathrm{C}$. The fixed cells were analyzed with flow cytometry (Becton Dickinson, San Jose, CA, USA) using the Alexa Fluor 488 Annexin V/Propidium iodide Apoptosis Assay kit (Invitrogen) following the manufacturer's instructions.

Total lysates obtained from A549 cells and with or without PinX1 siRNA were used to perform a Cell Cycle Antibody Array according to the manufacture's protocol (Full Moon BioSystems, Inc., Sunnyvale, CA, USA).

\section{Xenograft assay}

According to institutional guidelines, female 5-week-old athymic nude mice were used for in vivo experiments. Cells $\left(5 \times 10^{6}\right.$ A549-vector, $5 \times 10^{6}$ A549-PinX1 shRNA, $5 \times 10^{6}$ SK-MES-1， $5 \times 10^{6}$ SK-MES-1 PinX1) were injected into the lateral aspect of the rear leg. The tumor diameters were measured with calipers every 4 days, and tumor volumes were calculated (width ${ }^{2} \times$ length $/ 2$ ).

\section{Statistical analysis}

All statistical analysis was performed using SPSS software (SPSS Standard v 17.0). The associations between PinX1 expression and clinical-pathological features were assessed with the Chi-square test. Receiver-operator curve (ROC) analysis was performed to determine the cut-off scores for the PinX1 positivity. Survival curves were plotted by Kaplan-Meier analysis and compared by the log-rank test. Multiple Cox proportional hazards regression analysis was carried out to assess the significance of variables for survival. The correlation between expression of PinX1 and BMP5 was performed with the Fisher's exact test. Data derived from cell line and xenografts experiments are presented as mean \pm SE and assessed by the student's test. $P$ values of $<0.05$ were considered significant.

\section{Results}

Deletion of PinX1 gene and decreased expression of PinX1 in NSCLC patients

The bioinformatics analysis was first performed to detect PinX1 gene alterations in NSCLC, using cBioportal Web resource online (cBioportal for Cancer Genomic). The deletion of PinX1 gene accounted for the most alterations and was visualized in six NSCLC database (Lung Adenocarcinoma - Broad, Cell 2012; TCGA, Provisional; TCGA, Nature 2014; TSP, Nature 2008; Lung Squamous Carcinoma - TCGA, Provisional; TCGA, Nature 2012) (Fig. 1a). There were more PinX1 homozygous deletions and PinX1 heterozygous deficiencies and less PinX1 amplifications in two specific NSCLC datasets (namely Lung Squamous
Carcinoma - TCGA, Provisional and Lung Adenocarcinoma -TCGA, Provisional) (Fig. 1b).

To verify the results observed from historical data on cBioportal for Cancer Genomic, we selected primary NSCLC tissue samples from our affiliated hospitals. In these selected primary NSCLC tissues, PinX1 mRNA expression was observed in 8 out of $12(66.7 \%)$ NSCLC samples as compared to their normal counterparts by qRT-PCR (Fig. 1c). Western blot analyses revealed that 7 out of 12 (58.3\%) NSCLC samples had decreased PinX1 expression, when compared with adjacent normal lung tissues (Fig. 1d).

\section{PinX1 associated with NSCLC patients' clinicopathological features}

Immunohistochemistry was utilized to examine the expression of PinX1 in NSCLC patients (Fig. 2b). According to the ROC curve (Fig. 2a, Additional file 2: Table S1 and Additional file 3: Figure S1), low expression of PinX1 was discovered in 56/93 (60.2\%) in the learning cohort and 27/ $51(52.9 \%)$ in the validation cohort. As shown in Table 1, the association between PinX1 expression and the clinical-pathological parameters in learning cohort and validation cohort suggested that low expression of PinX1 is significantly associated with NSCLC patients' smoking condition, histological type, $\mathrm{T}$ stage, $\mathrm{N}$ stage, $\mathrm{M}$ stage and TNM stage. However, no significant associated between PinX1 expression and other clinical-pathological features, such as age, gender, WHO grade (Table 1).

\section{PinX1 serves as an independent indicator for NSCLC patients' poor survival}

In univariate analysis, Kaplan-Meier analysis also demonstrated a significant impact of well-known clinicopathological prognostic parameters, such as Smoking Condition $(P=0.000$ and 0.042 , respectively), $\mathrm{T}$ stage $(P=0.000$ and 0.009 , respectively), $\mathrm{N}$ stage $(P=0.000$ and 0.011 , respectively), $\mathrm{M}$ stage ( $p=0.000$ and 0.004 , respectively), TNM stage $(P=0.003$ and 0.008 , respectively) on NSCLC patient's survival in both cohorts (Table 2). However, these parameters, such as Age $(\mathrm{P}=0.199$ and 0.899 , respectively), Gender ( $\mathrm{P}=0.996$ and 0.385 , respectively), Histological Type $(\mathrm{P}=0.293$ and 0.252 , respectively) had no correlation with NSCLC patient's survival in both cohorts (Table 2). Furthermore, low PinX1 staining was correlated with poor survival of NSCLC patient in the learning cohort (media 21 months versus 34 months, $P=0.008$ ) and in the validation cohort (media 18 months versus 34 months, $P=0.005$ ) (Fig. $2 c$ ). In addition, PinX1 gene alteration also correlated with overall survival (media 38.47 months versus 52.56 months, $P=0.0353$ ) and Disease-free survival (media 17.0 months versus 51.51 months, $P=0.000$ ), which is explored in cBioportal Web resource online (Fig. 2d). In multivariate analysis, the expression of PinX1 expression was found 


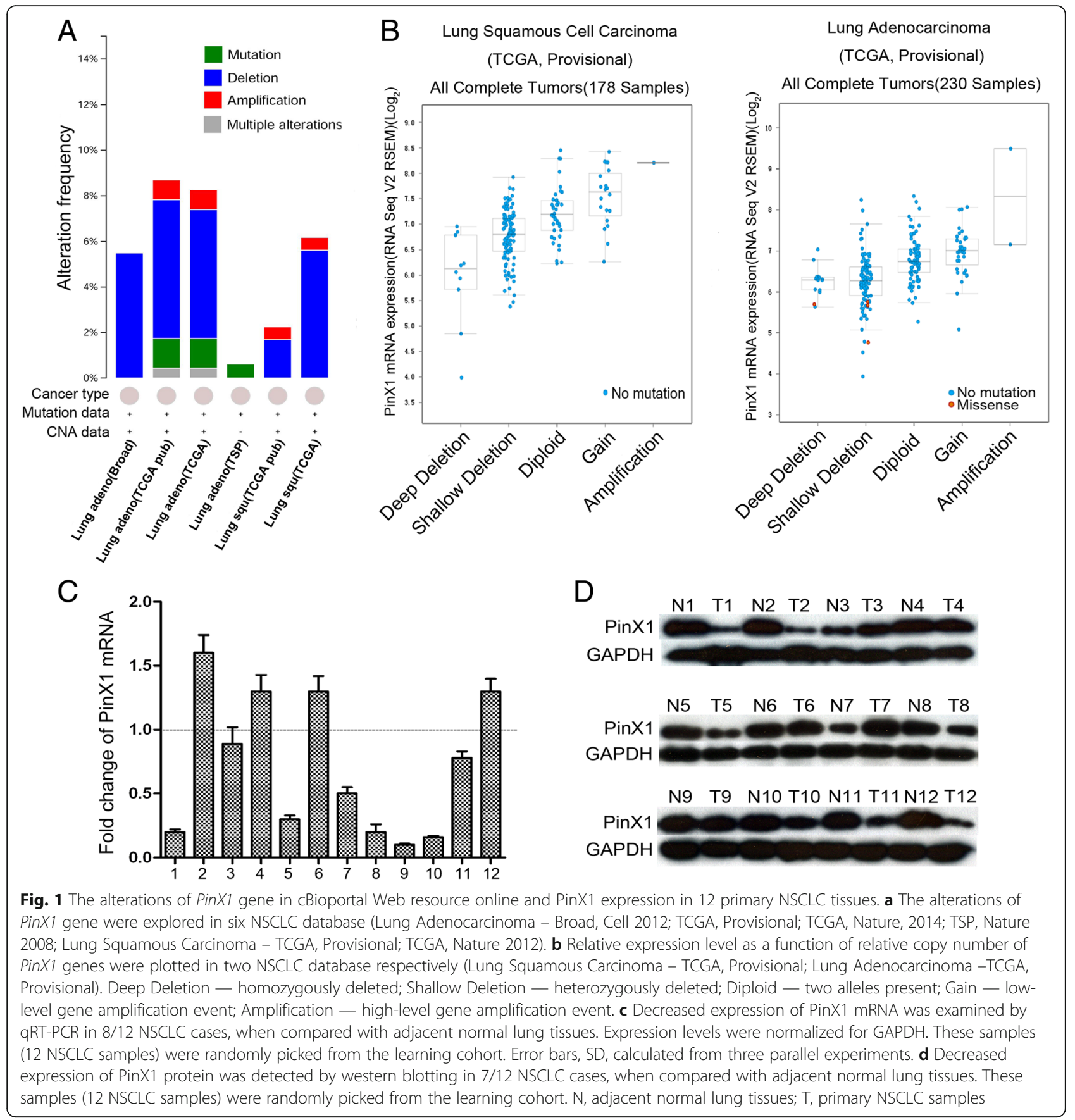

to be an independent prognostic factor for NSCLC patients' survival in the learning cohort $(P=0.046)$ and in validation cohort $(P=0.023)$ (Table 3$)$.

\section{PinX1 suppresses cell proliferation and clonogenicity of NSCLC cell lines in vitro}

We continued our study in vitro by investigating how PinX1 levels correlate with NSCLC cell survival. Of the four NSCLC cell lines (SK-MES-1, H125, A549, H1299) analyzed by Western blot, and all four lines showed lower levels of endogenous PinX1 than those in normal control lung tissues (Fig. 3a). Next, we choose to decrease the PinX1 expression in A549 and H1299, which have higher PinX1 expression among the four cell lines. Meanwhile, we further increased PinX1 expression in SK-MES-1 which has the lowest PinX1 expression. We examined $\mathrm{Bcl}-2$ and Bax protein levels, and discovered that the ratio of Bcl-2/Bax expression was substantially enhanced in PinX1-silenced SK-MES-1 cells and reduced in PinX1expression A549 and H1299 cells (Fig. 3b). A subsequent 


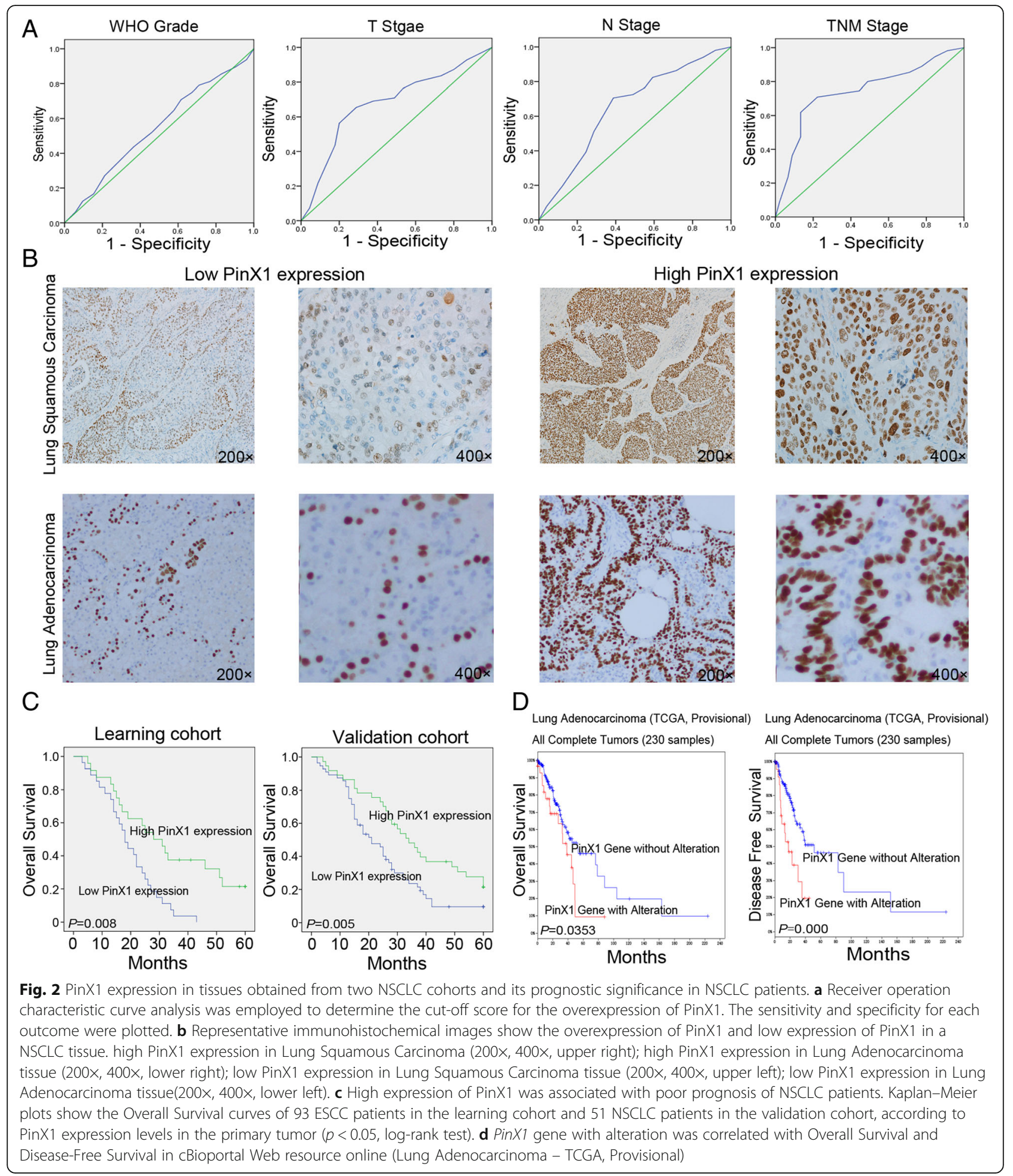

MTT analysis and colony-forming assay showed that both A549 and H1299 cells transfected with PinX1 siRNA and/ or PinX1 displayed a substantial increase in cell proliferation and/or clone capacity compared with control cells after PinX1 knockdown, while the reintroduction of PinX1 in SK-MES-1 cell line suppressed the cell viability and/or clone ability (Fig. $3 \mathrm{c}$ and d). In addition, we also observed that knocked-down PinX1 expression in BEAS-2B cells (Normal lung epithelial cells), the survival capacity of cells was substantially enhanced, and BEAS-2B transfected with 
Table 2 Clinical pathological parameters and expression of PinX1 for prognosis of NSCLC patients by univariate survival analysis (Long-rank test)

\begin{tabular}{|c|c|c|c|c|c|c|c|c|}
\hline \multirow[t]{2}{*}{ Variable } & \multicolumn{4}{|c|}{ Learning cohort } & \multicolumn{4}{|c|}{ Validation cohort } \\
\hline & Cases & $\begin{array}{l}\text { Mean survival } \\
\text { (months) }\end{array}$ & $\begin{array}{l}\text { Media survival } \\
\text { (months) }\end{array}$ & $P$-value* & Cases & $\begin{array}{l}\text { Mean survival } \\
\text { (months) }\end{array}$ & $\begin{array}{l}\text { Media survival } \\
\text { (months) }\end{array}$ & $P$-value* \\
\hline \multicolumn{9}{|l|}{ Age(years) } \\
\hline$<56^{\mathrm{a}}$ & 42 & 27.6 & 25 & 0.199 & 22 & 26.3 & 21 & 0.899 \\
\hline$\geq 56^{\mathrm{a}}$ & 51 & 31.8 & 29 & & 29 & 25.6 & 22 & \\
\hline \multicolumn{9}{|l|}{ Gender } \\
\hline Male & 61 & 29.4 & 27 & 0.996 & 35 & 24.2 & 19 & 0.385 \\
\hline Female & 32 & 29.7 & 26 & & 16 & 29.6 & 22 & \\
\hline \multicolumn{9}{|l|}{ Smoking Condition } \\
\hline Smoker & 42 & 22.5 & 18 & 0.000 & 20 & 20.1 & 17 & 0.042 \\
\hline Nonsmoker & 51 & 35.4 & 33 & & 31 & 29.7 & 27 & \\
\hline \multicolumn{9}{|l|}{ WHO grade } \\
\hline G1 & 28 & 28.1 & 21 & 0.942 & 16 & 17.5 & 14 & 0.012 \\
\hline G2 & 37 & 30.3 & 27 & & 20 & 26.4 & 22 & \\
\hline G3 & 28 & 29.8 & 32 & & 15 & 34.2 & 29 & \\
\hline \multicolumn{9}{|l|}{ Histological Type } \\
\hline Squamous cell carcinoma & 37 & 26.5 & 21 & 0.293 & 22 & 21.3 & 18 & 0.252 \\
\hline Adenocarcinoma & 46 & 29.8 & 27 & & 23 & 28.2 & 24 & \\
\hline Others & 10 & 36.5 & 32 & & 6 & 35.2 & 27 & \\
\hline \multicolumn{9}{|l|}{ T stage } \\
\hline $\mathrm{T} 1-\mathrm{T} 2$ & 38 & 39.1 & 37 & 0.000 & 18 & 31.6 & 31 & 0.009 \\
\hline T3-T4 & 55 & 22.4 & 16 & & 33 & 23.3 & 19 & \\
\hline \multicolumn{9}{|l|}{ N stage } \\
\hline No & 26 & 43.4 & 49 & 0.000 & 16 & 35.6 & 27 & 0.011 \\
\hline N1-N3 & 67 & 24.1 & 21 & & 35 & 21.4 & 18 & \\
\hline \multicolumn{9}{|l|}{ M stage } \\
\hline MO & 66 & 35.6 & 34 & 0.000 & 35 & 30 & 25 & 0.004 \\
\hline M1 & 27 & 15 & 12 & & 16 & 17 & 15 & \\
\hline \multicolumn{9}{|l|}{ TNM stage } \\
\hline$|-| \mid$ & 25 & 38.9 & 38 & 0.003 & 14 & 36.5 & 27 & 0.008 \\
\hline III-IV & 68 & 26 & 24 & & 37 & 21.8 & 18 & \\
\hline \multicolumn{9}{|l|}{ Pin $\mathrm{X} 1$ expression } \\
\hline Negative & 56 & 24.8 & 21 & 0.008 & 27 & 19.4 & 18 & 0.005 \\
\hline Positive & 37 & 36.2 & 34 & & 24 & 32.6 & 28 & \\
\hline
\end{tabular}

*Long-rank test ${ }^{\mathrm{a}}$ Mean age; $T$ tumor, $N$ node, $M$ metastases

PinX1 displayed a substantial drop compared with that of control cells (Additional file 4: Figure S2).

PinX1 arrested G1/S phase transition of the cell cycle According to our previous study, we asked whether downregulation of PinX1 influenced the cell cycle in G1/S phase. An EdU cooperation assay and flow cytometry were used to analyze the potential mechanisms of PinX1 suppresses NSCLC cells proliferation. As shown in Fig. 4a and $\mathrm{b}$, the EdU positive cells were dramatically boosted in the both PinX1-silenced cells and significant reduced in PinX1-overexpression cells compare with that control cells. Knockdown of PinX1 resulted in a decrease in the percentage of cells in the G0/G1 phase from $63.4 \%, 57.7 \%$ in control cells to 50.5\%, 49.6\% in H1299 and A549 cells lines transfected with PinX1 siRNA respectively. Additionally, the population of cells in S phase also displayed the same trend from $17.2 \%, 20.1 \%$ in control cells to $29.3 \%$, 
Table 3 Multivariate Cox regression analysis for NSCLC patients

\begin{tabular}{|c|c|c|c|c|c|c|}
\hline \multirow[t]{2}{*}{ Variable } & \multicolumn{3}{|c|}{ Learning cohort } & \multicolumn{3}{|c|}{ Validation cohort } \\
\hline & $\mathrm{HR}$ & $95 \% \mathrm{Cl}$ & $P$-value & $\mathrm{HR}$ & $95 \% \mathrm{Cl}$ & $P$-value \\
\hline PinX1 expression & 0.577 & $0.335-0.991$ & 0.046 & 0.441 & $0.191-0.882$ & 0.023 \\
\hline T stage & 2.061 & $1.222-3.482$ & 0.007 & 5.434 & $2.162-13.660$ & 0.000 \\
\hline N stage & 2.590 & $1.340-5.009$ & 0.005 & 2.392 & $1.113-5.141$ & 0.000 \\
\hline M stage & 4.886 & $2.766-8.630$ & 0.000 & 3.485 & $1.777-6.837$ & 0.000 \\
\hline TNM stage & 2.725 & $1.330-5.584$ & 0.006 & 2.743 & $1.331-5.650$ & 0.006 \\
\hline
\end{tabular}

31.7\% in PinX1-slienced cells. Simultaneously, an increase in the percentage of cells in G0/G1 phase from $56.8 \%$ in control cells to $66.9 \%$ and $S$ phase from $25.4 \%$ in control cells to $15.9 \%$ in PinX1-overexpression cells (Fig. 4c and d). These findings indicated that PinX1 in blocking G1 to $\mathrm{S}$ phase transition might contribute to NSCLC cells survival ability.
PinX1 correlated P15 and cyclinD1 expression in NSCLC cells To identify the molecular basis of PinX1 regulation of target proteins in NSCLC cells transition from G0/G1 phase to $\mathrm{S}$ phase, the expression of several relevant activators or inhibitors of the cell cycle were detected by antibody microarrays and western blot assay in PinX1-silenced A549 cells. In this antibody arrays, we discovered the expression

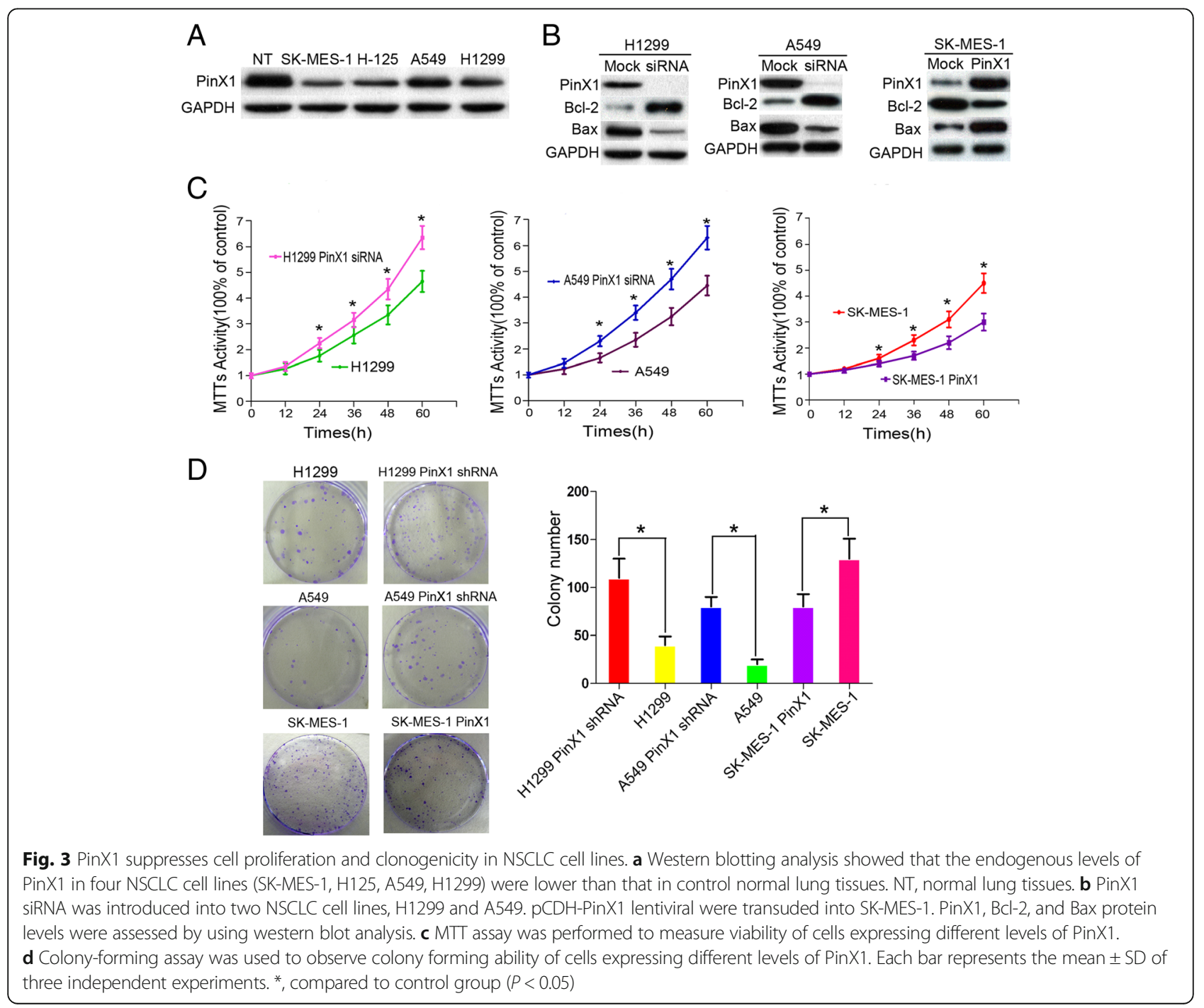




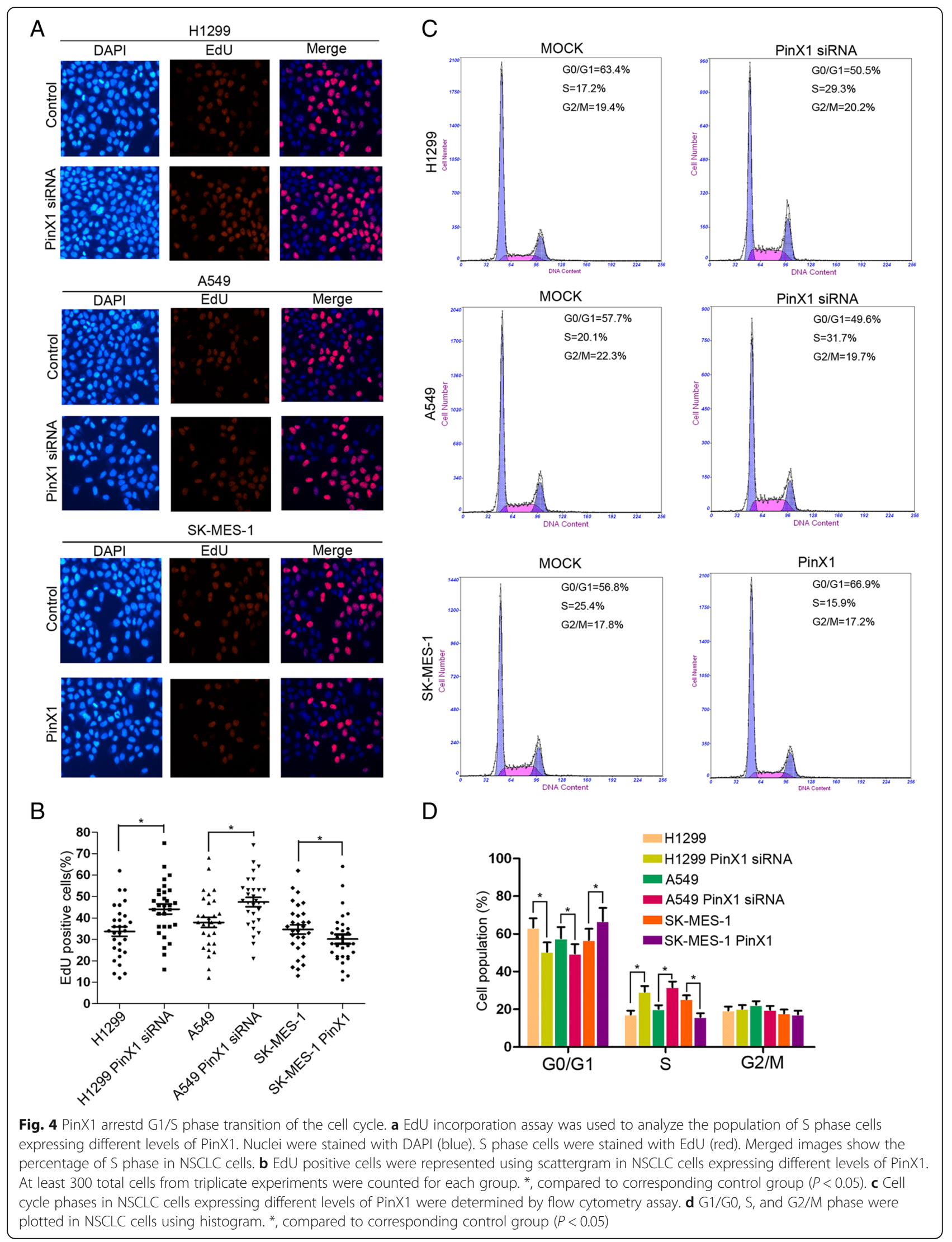


of $\mathrm{P} 15^{\mathrm{INK} 4 \mathrm{~b}}$ and $\mathrm{Rb}$ decreased 0.4-, 0.18- fold and the expression of CDK4, CyclinD1, CyclinD2, p-Rb(p-Ser608) were increased 0.25-, 0.31-, 0.2-, 0.5- fold in PinX1slienced A549 cells (Fig. 5a). Furthermore, western blot also confirmed that decreased $\mathrm{P} 15^{\mathrm{INK} 4 \mathrm{~b}}$ and increased CDK4, CyclinD1, p-Rb(P-Ser608) expression were observed in PinX1-slienced A549 cells (Fig. 5c). These results indicated that $\mathrm{P} 15 /$ cyclinD1 pathway might contribute to the PinX1-arrested G0/G1 to S phase transition.

PinX1 silencing increases xenograft tumor growth in vivo Xenograft assay was used to investigate if PinX1 knockdown could stimulate NSCLC cells proliferation in vivo. As shown in Fig. 5b, tumors from nude mice injected with A549-PinX1shRNA grew much faster and weighed significantly more at day 44 (mean tumor volume of $200 \mathrm{~mm}^{3}$ to $1820 \pm 155 \mathrm{~mm}^{3}$ ), compared to control A459 tumors (mean tumor volume of $200 \mathrm{~mm}^{3}$ to 1420 $\left.\pm 138 \mathrm{~mm}^{3}, P<0.05\right)$. Furthermore, the growth of the SK-MES-1-PinX1 tumors was substantially suppressed (a mean tumor volume of $1220 \pm 116 \mathrm{~mm}^{3}$ ), compared with that in control SK-MES-1 tumors (a mean tumor volume of $\left.896 \pm 95 \mathrm{~mm}^{3}, P<0.05\right)$.

\section{PinX1 associated with cell proliferation and cell cycle transition relies on BMP5 in NSCLC cell lines}

According to another study, the differentially expressed mRNAs were identified by mRNA microarray analysis in PinX1 overexpressed group. The fold change (14.54) of BMP5 was significantly increased in microarray analysis and was expressed at the highest levels [25]. Therefore, BMP5 was involved in PinX1-slienced A549 cells and PinX1-overexpressed SK-MES-1 cells to understand the possible molecules of PinX1 act on P15/cyclinD1 pathway. As it shown in Fig. 5d, BMP5 expression was significantly decreased in PinX1-slienced A549 cells, and increased in PinX1-overexpressed SK-MES-1 cells. As it shown in Fig. 6a, Bcl-2/P-Rb expression was up-regulated in PinX1slienced A549 cells and was down-regulated in PinX1overexpressed SK-MES-1 cells. Bax/P15 ${ }^{\mathrm{INK}}$ expression was

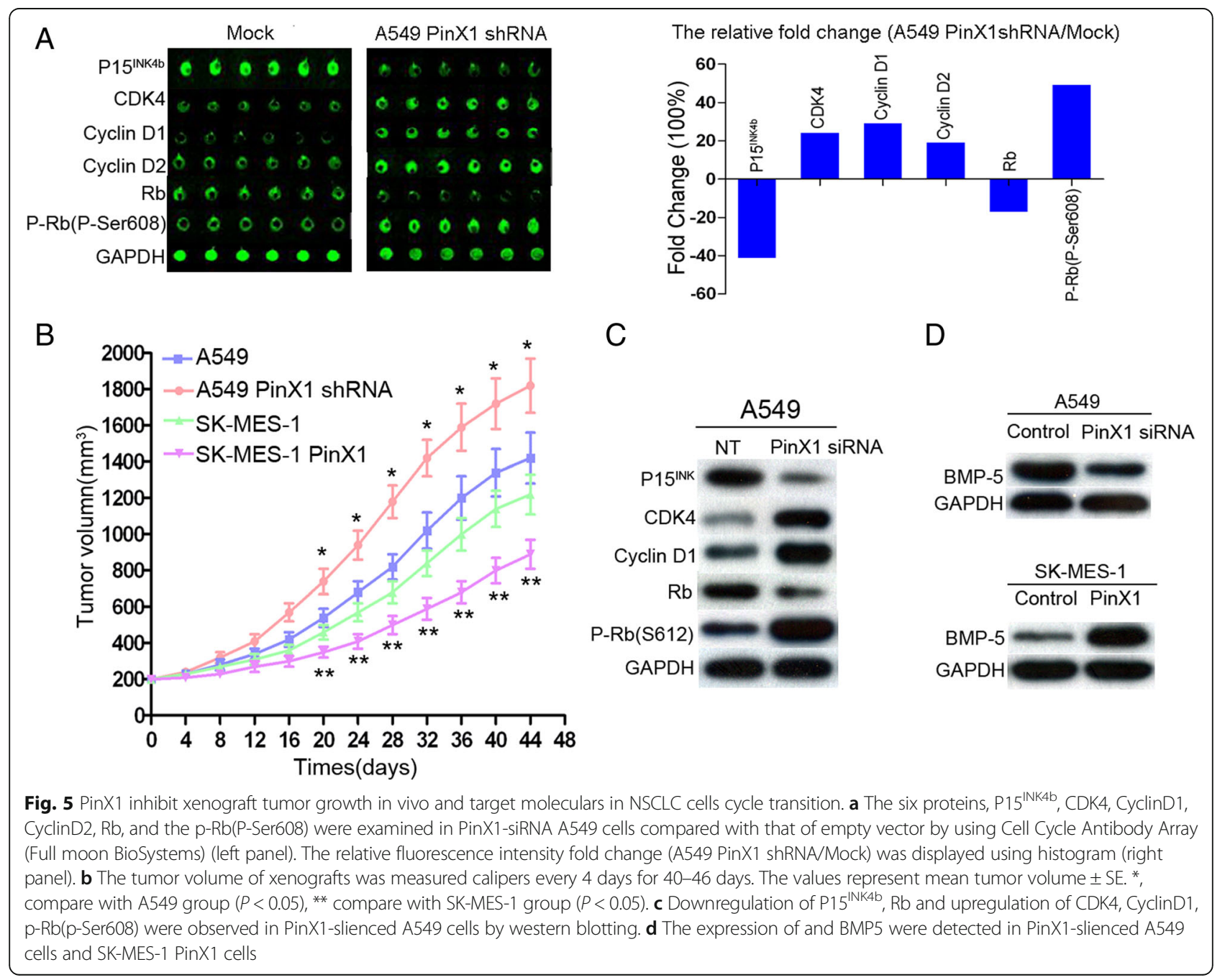




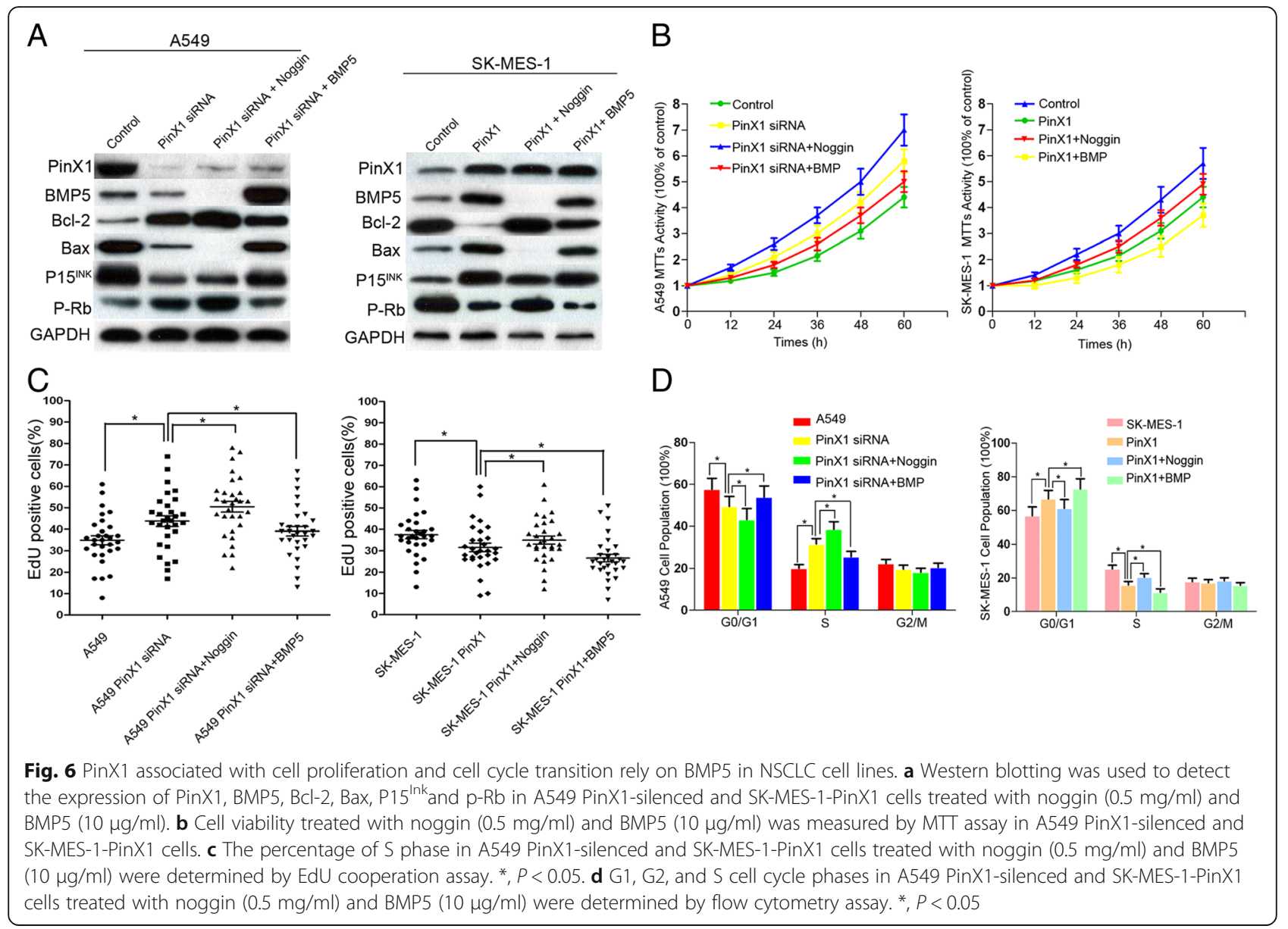

decreased in PinX1-slienced A549 cells and increased in PinX1-overexpressed SK-MES-1 cells. After introducing BMP5-inhibitor noggin, Bcl-2/P-Rb expression was increased and Bax $/ \mathrm{P} 15^{\mathrm{INK}}$ expression was decreased in PinX1-overexpressed SK-MES-1 cells. Moreover, Bcl-2/ $\mathrm{P}-\mathrm{Rb}$ expression was decreased and Bax $/ \mathrm{P} 15^{\mathrm{INK}}$ expression was increased in PinX1-slienced A549 cells by BMP $(10 \mu \mathrm{g} / \mathrm{ml})$ treatment (Fig. 6a). Next, MTT analysis, flow cytometry and EdU cooperation assay further demonstrated that the function of PinX1 in cell proliferation was inhibited by noggin and restored by BMP- 5 (Fig. 6b, c and d). Together, these results support the notion the BMP5 may be important for PinX1 mediated cell cycle and its expression may be related to NSCLC proliferation.

\section{Correlation between the expression of PinX1 and BMP5 in NSCLC patients}

Utilizing the previously criterions of a semi-quantitative scale evaluation, low expression of BMP5 was observed in $41 / 93(44.1 \%)$ in the learning cohort and $23 / 51$ (45.1\%) in the validation cohort. Further correlation analysis demonstrated that a prominently consistency correlation between PinX1 expression and BMP5 in both cohorts $(P=0.015$ in learning cohort and $P=0.006$ in validation cohort, Fisher's exact test, Table 4).

Table 4 Correlation between expression of PinX1 and BMP5 in NSCLC patients

\begin{tabular}{|c|c|c|c|c|c|c|c|c|}
\hline & \multicolumn{4}{|c|}{ Learning cohort } & \multicolumn{4}{|c|}{ Validation cohort } \\
\hline & Cases & $\begin{array}{l}\text { BMP-5 Low } \\
\text { expression (\%) }\end{array}$ & $\begin{array}{l}\text { BMP-5 High } \\
\text { expression (\%) }\end{array}$ & $P$-value & Cases & $\begin{array}{l}\text { BMP-5 Low } \\
\text { expression (\%) }\end{array}$ & $\begin{array}{l}\text { BMP-5 High } \\
\text { expression (\%) }\end{array}$ & $P$-value \\
\hline $\begin{array}{l}\text { PinX1 Negative } \\
\text { expression }\end{array}$ & 56 & $31(33.3 \%)$ & $25(26.9 \%)$ & $P=0.015(r=0.252)$ & 27 & 17(33.3\%) & $10(19.6 \%)$ & $P=0.006(r=0.381)$ \\
\hline $\begin{array}{l}\text { PinX1 Positive } \\
\text { expression }\end{array}$ & 37 & $10(10.8 \%)$ & $27(29 \%)$ & & 24 & $6(11.8 \%)$ & 18(35.3\%) & \\
\hline
\end{tabular}




\section{Discussion}

PinX1 is a newly cloned gene that has been mapped to chromosome 8P23.1 [26]. However, the molecular status of PinX1 and its attendant expression patterns are vastly different in various tissues and tumors types. This variation suggests that abnormal gene regulation and/or protein functions of PinX1 in tumorigenesis are complicated and are likely to be tumor-type-specific [27-29].

Our initial observations focused on the incidence of PinX1 alteration frequency in NSCLC from cBioportal Web resource online [30]. In agreement with previously studies, the PinX1 mRNA Sqe analysis demonstrated that the frequency of gene PinX1 homozygous deletion occurs in NSCLC tumorigenesis [19, 26, 31]. Western blotting and qRT-PCR assay also demonstrated that the protein and mRNA expression of PinX1 was decreased in 12 primary NSCLC tissues. Therefore, immunohistochemistry for PinX1 was performed following on two independent cohort of NSCLC with complete clinicalpathological and follow-up data. Conventionally, the expression of PinX1 in two cohorts NSCLC patients in keeping with preliminary experiments was frequently suppressed in NSCLC tissues by using a scoring system [20]. The decreased PinX1 staining was found to correlate with smoking condition, Histological Type, T stage, $\mathrm{N}$ stage, TNM stage. Moreover, univariate and multivariate analysis in both NSCLC cohort as well as data from the cBioportal for Cancer Genomic demonstrated that PinX1 expression was a strong and independent prognostic indicator for NSCLC disease. Our clinical data analysis indicated that the PinX1 expression might provide useful information in the evaluation prognosis and follow-up schedule guiding for NSCLC patients.

Together, these results propel us to further elucidate a potentially important role of PinX1 as an underlying biological mechanism in the development and/or growth of NSCLC. It has been reported that PinX1 suppress tumor growth and depletion of endogenous PinX1 enhanced tumorigenicity [32]. We observed that knockdown of PinX1 could also enhance cell proliferation and clonogenicity of NSCLC cell lines in vitro. Besides, the capacity of cell inhibition and survival enhancement in PinX1 was also proved in vivo by nude xenograft assay. Several studies discovered that localization of PinX1 extends beyond the tail of telomere, suggesting a novel cell cycle functions outside the telomerase inhibition [14, 15, 33]. Therefore, we analyzed cell cycle in PinX1-slienced and PinX1overexpression NSCLC cells by EdU cooperation assay and flow cytometry assay. The cell cycle analysis showed that decreased PinX1 expression could accelerate G1 to S phase transition and this acceleration might contribute to NSCLC cells survival ability.

To identify the molecular events involving in PinX1 arrested G1/S transition, we carried out a large-scale proteomic screening using antibody microarray (Full Moon BioSystems) to detect the changes of cell cycle related protein in PinX1-slienced NSCLC cells. Of the 60 cell cycle related proteins, six study-related proteins were differentially observed by 0.2 -fold or more (increased: CDK4, CyclinD1, CyclinD2, P-Rb(P-Ser608); decreased: $\left.\mathrm{P} 15^{\mathrm{INK} 4 \mathrm{~b}}, \mathrm{Rb}\right)$. Subsequently, these screened cell cycle related proteins expressions were confirmed by western blot assay again. The decreased P15 and increased cyclinD1 protein expression lead to retinoblastoma $(\mathrm{Rb})$ phosphorylation, subsequent progression of G1/S phase transition and acceleration of uncontrolled cell proliferation [34]. We suggest that this might be the reason, why there PinX1 correlated with NSCLC tumorigenesis and progression.

According to an mRNA and IncRNA expression profile screening from other group PinX1-related reports, the differentially expressed mRNAs were identified by the fold change in pcDNA3.1-PinX1 group. The fold change of BMP5 mRNA (14.54) was significantly increased in pcDNA3.1-PinX1 group and was expressed at the highest levels. Therefore, we focus on BMP5 to further elucidate the possible molecular mechanism of PinX1's action via act P15/cyclinD1 pathway [25]. BMP5 was originally identified by their presence in bone-inductive extracts of dematerialized bone and belongs to the transforming growth factor- $\beta$ (TGF- $\beta$ ) superfamily $[35,36]$. It binds and activates TGF- $\beta$ RI (TGF- $\beta$ type I receptor) and TGF- $\beta$ RII (TGF- $\beta$ type II receptor) and then phosphorylates Smad1/ $5 / 8$. The phosphorylated Smad1/5/8 together with Smad4 translocated into nucleus and control cycle progression [37]. It has been reported that the mRNA levels of BMP5 was significantly decreased in NSCLC tissues [38]. In this study, the changes of downstream protein BMP5 correlated with PinX1-stimulated cell proliferation. Furthermore, a consistent correlation of PinX1 expression and BMP5 expression in two NSCLC cohorts, as well as the inhibition of noggin and the promotion of ectogenic BMP5 in vitro assay confirmed that BMP5 might be the key molecule contribute to PinX1-inhibited cell proliferation and cell cycle transition.

\section{Conclusions}

We describe, for the first time, the expression pattern of PinX1 in human NSCLC tissues. Our results provide a basis for the concept that decreased expression PinX1 may be important in NSCLC tumorigenesis, and might be a novel predictor for NSCLC patients. Furthermore, the function and mechanistic studies of PinX1 suggest that PinX1-arrested cell cycle transition accounts for the NSCLC's cell proliferation. In addition, the function of PinX1 in cell cycle transition via BMP5 and P15/cyclinD1 pathway might be responsible for the development and progression of human NSCLC disease. 


\section{Additional files}

Additional file 1: Supplementary materials and methods. (DOCX $15 \mathrm{~kb}$ ) Additional file 2: Table S1. Area under the receiver-operator curve of PinX1 for each pathological feature in both NSCLC cohorts (DOCX $13 \mathrm{~kb}$ )

Additional file 3: Figure S1. Receiver-operator curves (ROC) were used to determine the cut-off score for positive expression of PinX1 protein in both cohorts. The sensitivity and specificity for each outcome were plotted: (A). Gender in learning cohort, (B) M stage in learning cohort, (C) Gender in validation cohort, (D) M stage in validation cohort, (E) T stage in validation cohort, (F) N stage in validation cohort, (G) WHO grade in validation cohort, $(\mathrm{H})$ TNM stage in validation cohort. (TIF $531 \mathrm{~kb}$ )

Additional file 4: Figure S2. MTT assay was performed to measure viability of BEAS-2B cells expressing different levels of PinX1. The survival capacity of cells was substantially enhanced in PinX1-silenced BEAS-2B cells (Normal lung epithelial cells). Transfected with PinX1 in BEAS-2B cells displayed a substantial drop in cell viability compared with that of control cells. Each bar represents the mean \pm SD of three independent experiments. * , compared to control group $(P<0.05)$. (TIF $226 \mathrm{~kb})$

\section{Abbreviations}

CDK4: Cyclin-dependent kinase 4; CGA: The Cancer Genome Atlas; IHC: Immunohistochemistry; IPP: Image pro plus; NSCLC: Non-small cell lung cancer; qRT-PCR: Quantitative real-time polymerase chain reaction; Rb: Retinoblastoma; ROC: Receiver-operator curve; TRF1: Telomeric repeat binding factor 1

\section{Funding}

This study was supported by Research grants from the 973 Project of China (No. 2010CB912802) and the National Nature Science Foundation of China (No. 81603137).

\section{Authors' contributions}

DX involved in the study concept and design; XHJ, ML and JXZ provided sample and clinical data; WJH performed statistical analysis; JXZ and XD drafted the manuscript. All authors read and approved the final manuscript.

\section{Competing interests}

The authors declare that they have no competing interests.

\section{Consent for publication}

No applicable.

\section{Ethics approval and consent to participate}

The research protocol study was reviewed and approved by the Medical Ethics Committee of the Sun Yat-Sen University and involved only informed consent patients.

\section{Publisher's Note}

Springer Nature remains neutral with regard to jurisdictional claims in published maps and institutional affiliations.

\section{Author details}

'Zhongshan School of Medicine, Sun Yat-Sen University, Guangzhou, China. ${ }^{2}$ State Key Laboratory of Oncology in South China, Cancer Center, Sun Yat-Sen University, Guangzhou, China. ${ }^{3}$ Department of Pathology, Cancer Center, Sun Yat-Sen University, Guangzhou, China. ${ }^{4}$ Department of Oncology, The first Affiliated Hospital, Sun Yat-Sen University, No.58, Zhongshan Second Road, 510080 Guangzhou, China.
}

Received: 26 July 2016 Accepted: 13 March 2017 Published online: 04 April 2017

\section{References}

1. Torre LA, Bray F, Siegel RL, Ferlay J, Lortet-Tieulent J, Jemal A. Global cancer statistics, 2012. CA Cancer J Clin. 2015;65:87-108.
2. Aarts MJ, van den Borne BE, Biesma B, Kloover JS, Aerts JG, Lemmens VE. Improvement in population-based survival of stage IV NSCLC due to increased use of chemotherapy. Int J Cancer. 2015;136:E387-95.

3. Patnaik SK, Kannisto E, Knudsen S, Yendamuri S. Evaluation of microRNA expression profiles that may predict recurrence of localized stage I nonsmall cell lung cancer after surgical resection. Cancer Res. 2010;70:36-45.

4. Warth A. Diagnosis, prognosis, and prediction of non-small cell lung cancer: Importance of morphology, immunohistochemistry and molecular pathology. Pathologe. 2015;36 Suppl 2:194-200.

5. Yu Y, He J. Molecular classification of non-small-cell lung cancer: diagnosis, individualized treatment, and prognosis. Front Med. 2013;7:157-71.

6. Banik SS, Counter CM. Characterization of interactions between PinX1 and human telomerase subunits hTERT and hTR. J Biol Chem. 2004;279: 51745-8.

7. Johnson FB. PinX1 the tail on the chromosome. J Clin Invest. 2011;121:1242-4

8. Zhou XZ. PinX1: a sought-after major tumor suppressor at human chromosome 8p23. Oncotarget. 2011;2:810-9.

9. Zhou XZ, Huang P, Shi R, Lee TH, Lu G, Zhang Z, Bronson R, Lu KP. The telomerase inhibitor PinX1 is a major haploinsufficient tumor suppressor essential for chromosome stability in mice. J Clin Invest. 2011;121:1266-82.

10. Zhang $B$, Bai $Y X, M a H H$, Feng $F$, Jin R, Wang ZL, Lin J, Sun SP, Yang $P$, Wang $X X$, et al. Silencing PinX1 compromises telomere length maintenance as well as tumorigenicity in telomerase-positive human cancer cells. Cancer Res. 2009;69:75-83.

11. Zhang B, Qian D, Ma HH, Jin R, Yang PX, Cai MY, Liu YH, Liao YJ, Deng HX, Mai SJ, et al. Anthracyclines disrupt telomere maintenance by telomerase through inducing PinX1 ubiquitination and degradation. Oncogene. 2012;31:1-12.

12. Zuo J, Wang DH, Zhang YJ, Liu L, Liu FL, Liu W. Expression and mechanism of PinX1 and telomerase activity in the carcinogenesis of esophageal epithelial cells. Oncol Rep. 2013;30:1823-31.

13. Song H, Li Y, Chen G, Xing Z, Zhao J, Yokoyama KK, Li T, Zhao M. Human MCRS2, a cell-cycle-dependent protein, associates with LPTS/PinX1 and reduces the telomere length. Biochem Biophys Res Commun. 2004;316:1116-23.

14. Yuan K, Li N, Jiang K, Zhu T, Huo Y, Wang C, Lu J, Shaw A, Thomas K, Zhang , et al. PinX1 is a novel microtubule-binding protein essential for accurate chromosome segregation. J Biol Chem. 2009;284:23072-82.

15. Yonekawa T, Yang S, Counter CM. PinX1 localizes to telomeres and stabilizes TRF1 at mitosis. Mol Cell Biol. 2012;32:1387-95

16. Qian D, Zhang B, He LR, Cai MY, Mai SJ, Liao YJ, Liu YH, Lin MC, Bian XW, Zeng $Y X$, et al. The telomere/telomerase binding factor $P i n X 1$ is a new target to improve the radiotherapy effect of oesophageal squamous cell carcinomas. J Pathol. 2013;229:765-74.

17. Li JP, Zhu SW, Chen YH, Wang XL, Gao X. Suppression of PinX1 resulted in telomere dysfunction and enhanced radiosensitivity in osteosarcoma cell lines. Neoplasma. 2015;62:887-93.

18. Tian XP, Qian D, He LR, Huang H, Mai SJ, Li CP, Huang XX, Cai MY, Liao YJ, Kung HF, et al. The telomere/telomerase binding factor $P$ in $X 1$ regulates paclitaxel sensitivity depending on spindle assembly checkpoint in human cervical squamous cell carcinomas. Cancer Lett. 2014;353:104-14.

19. Shi R, Zhao Z, Zhou H, Wei M, Ma WL, Zhou JY, Tan WL. Reduced expression of PinX1 correlates to progressive features in patients with prostate cancer. Cancer Cell Int. 2014;14:46.

20. Cai MY, Zhang B, He WP, Yang GF, Rao HL, Rao ZY, Wu QL, Guan XY, Kung HF, Zeng YX, Xie D. Decreased expression of PinX1 protein is correlated with tumor development and is a new independent poor prognostic factor in ovarian carcinoma. Cancer Sci. 2010;101:1543-9.

21. Ma Y, Wu L, Liu C, Xu L, Li D, Li JC. The correlation of genetic instability of PINX1 gene to clinico-pathological features of gastric cancer in the Chinese population. J Cancer Res Clin Oncol. 2009;135:431-7.

22. Li HL, Han L, Chen HR, Meng F, Liu QH, Pan ZQ, Bai J, Zheng JN. PinX1 serves as a potential prognostic indicator for clear cell renal cell carcinoma and inhibits its invasion and metastasis by suppressing MMP-2 via NFkappaB-dependent transcription. Oncotarget. 2015;6:21406-20.

23. Gao J, Aksoy BA, Dogrusoz U, Dresdner G, Gross B, Sumer SO, Sun Y, Jacobsen $A$, Sinha $R$, Larsson $E$, et al. Integrative analysis of complex cancer genomics and clinical profiles using the cBioPortal. Sci Signal. 2013;6:11.

24. Cerami E, Gao J, Dogrusoz U, Gross BE, Sumer SO, Aksoy BA, Jacobsen A Byrne CJ, Heuer ML, Larsson E, et al. The cBio cancer genomics portal: an open platform for exploring multidimensional cancer genomics data. Cancer Discov. 2012;2:401-4. 
25. Shi R, Zhou JY, Zhou H, Zhao Z, Liang SH, Zheng WL, Ma WL. The role of PinX1 in growth control of breast cancer cells and its potential molecular mechanism by mRNA and IncRNA expression profiles screening. Biomed Res Int. 2014;2014:978984.

26. Kondo T, Oue N, Mitani Y, Kuniyasu H, Noguchi T, Kuraoka K, Nakayama H, Yasui W. Loss of heterozygosity and histone hypoacetylation of the PINX1 gene are associated with reduced expression in gastric carcinoma. Oncogene. 2005;24:157-64

27. Akiyama Y, Maesawa C, Wada K, Fujisawa K, Itabashi T, Noda Y, Honda T, Sato N, Ishida K, Takagane A, Saito K, Masuda T. Human PinX1, a potent telomerase inhibitor, is not involved in human gastrointestinal tract carcinoma. Oncol Rep. 2004;11:871-4.

28. Hawkins GA, Chang BL, Zheng SL, Isaacs SD, Wiley KE, Bleecker ER, Walsh PC, Meyers DA, Xu J, Isaacs WB. Mutational analysis of PINX1 in hereditary prostate cancer. Prostate. 2004:60:298-302.

29. Kim MS, Kim SS, Yoo NJ, Lee SH. Somatic mutation of PINX1 gene is rare in common solid cancers. APMIS. 2012;120:770-1.

30. Klonowska K, Czubak K, Wojciechowska M, Handschuh L, Zmienko A, Figlerowicz M, Dams-Kozlowska H, Kozlowski P. Oncogenomic portals for the visualization and analysis of genome-wide cancer data. Oncotarget. 2016;7:176-92

31. Baichuan L, Cao S, Liu Y. LPTS: A Novel Tumor Suppressor Gene and a Promising Drug Target for Cancer Intervention. Recent Pat Anticancer Drug Discov. 2015;10:170-5.

32. Mei PJ, Chen YS, Du Y, Bai J, Zheng JN. PinX1 inhibits cell proliferation, migration and invasion in glioma cells. Med Oncol. 2015;32:73.

33. Cheung DH, Kung HF, Huang JJ, Shaw PC. PinX1 is involved in telomerase recruitment and regulates telomerase function by mediating its localization. FEBS Lett. 2012;586:3166-71.

34. Shcherba M, Liang Y, Fernandes D, Perez-Soler R, Cheng H. Cell cycle inhibitors for the treatment of NSCLC. Expert Opin Pharmacother. 2014;15:991-1004.

35. Waite KA, Eng C. From developmental disorder to heritable cancer: it's all in the BMP/TGF-beta family. Nat Rev Genet. 2003;4:763-73.

36. Shen Z, Kauttu T, Cao J, Seppanen H, Vainionpaa S, Ye Y, Wang S, Mustonen H, Puolakkainen P. Macrophage coculture enhanced invasion of gastric cancer cells via TGF-beta and BMP pathways. Scand J Gastroenterol. 2013;48:466-72.

37. Alarcon C, Zaromytidou Al, Xi Q, Gao S, Yu J, Fujisawa S, Barlas A, Miller AN, Manova-Todorova K, Macias MJ, et al. Nuclear CDKs drive Smad transcriptional activation and turnover in BMP and TGF-beta pathways. Cell. 2009;139:757-69.

38. Deng T, Lin D, Zhang M, Zhao Q, Li W, Zhong B, Deng Y, Fu X. Differential expression of bone morphogenetic protein 5 in human lung squamous cell carcinoma and adenocarcinoma. Acta Biochim Biophys Sin (Shanghai). 2015; 47:557-63.

\section{Submit your next manuscript to BioMed Central and we will help you at every step:}

- We accept pre-submission inquiries

- Our selector tool helps you to find the most relevant journal

- We provide round the clock customer support

- Convenient online submission

- Thorough peer review

- Inclusion in PubMed and all major indexing services

- Maximum visibility for your research

Submit your manuscript at www.biomedcentral.com/submit

C) Biomed Central 